\title{
A Review on Bioremediation of Heavy Metals in Contaminated Water
}

\author{
Arpita Kulshreshtha ${ }^{1}$, Ranu Agrawal ${ }^{2}$, Manika Barar ${ }^{2}$, Shilpi Saxena $^{2}$ \\ Department of Chemistry, Jiwaji University, Gwalior (M.P.), India \\ Department of Chemistry, C.C.S. University, Meerut (U.P.), India
}

\begin{abstract}
Bioremediation is considered as one of the safer, cleaner, cost effective and environmental friendly technology for decontaminating sites which are contaminated with wide range of pollutants. The term bioremediation has been introduced to describe the process of using biological agent to remove toxic waste from environment. Bioremediation is the most effective management tool to manage the polluted environment and recover contaminated soil. The process of bioremediation uses various agents such as bacteria, fungi, algae and higher plants as major tools in treating heavy metals present in the environment. Bioremediation, both In situ and ex-situ have also enjoyed strong scientific growth, in part due to the increased use of natural attenuation, since most natural attenuation is due to biodegradation. Bioremediation and natural attention are also seen as a solution for emerging contaminant problems. Microbes are very helpful to remediate the contaminated environment.
\end{abstract}

Keywords: Bioremediation, Heavy metals contamination, Pollutants, Microorganisms like bacteria and fungi, Ex situ bioremediation, In situ bioremediation

\section{Introduction}

Today environmental pollution is a very big problem because of hazardous waste has led to scarcity of clean water and disturbances of soil thus limiting crop production ${ }^{1}$. Bioremediation uses biological agents, mainly microorganisms i.e., bacteria, fungi and yeast to clean up contaminated water ${ }^{2}$. In bioremediation processes, microorganism use the contaminants as nutrient or energy sources ${ }^{3,4}$. The bioremediation and natural attenuation area has both basic research and field application foci for the environmental biotechnology. The basic research foci are co-metabolism, biotreatability, biotransformation kinetics, and modeling of biogeochemical assessment techniques, and modeling of attenuation and environmental fate ${ }^{5}$. Bioremediation process involves biotransformation and biodegradation by transforming contaminants to non -hazardous or less hazardous chemicals. Bioremediation is defined as the process by which microorganisms are stimulated to rapidly degrade hazardous organic pollutants to environmentally safe levels in ground water, soil, substances, materials and sediments. Recently, biological remediation process have also been devised to either precipitate effectively immobilize inorganic pollutants such as heavy metals. Stimulation of microorganisms is achieved by the addition of growth substances, nutrients, terminal electron acceptor or donors or some combination thereby resulting in an increase in organic pollutant degradation and bio-transformation. The energy and carbon are obtained through the metabolism or organic compounds by the microbes involved in bioremediation processes ${ }^{6,7}$. Often, the microorganisms metabolize the chemicals to produce carbon dioxide or methane, water and biomass. Biodegradation is the breaking down of organic or bioaccumulation and biotransformation of inorganic compounds into environmental friendly compounds.

Bioremediation may employed in order to attack specific contaminants, such as chlorinated pesticides that are degraded by bacteria, or a more general approach may be taken, such as oil spills that are broken down using multiple techniques including the addition of fertilizer to facilitate the decomposition of crude oil by bacteria. Not all contaminants are readily treated through the use of bioremediation; heavy metals such as cadmium, lead are not readily absorbed or captured by microorganism ${ }^{8}$. However, there are a number of advantages to bioremediation, which may be employed in areas which cannot be reached easily without excavation. The foundation of bioremediation has been the natural ability of microorganisms to degrade organic compounds. Bioremediation is not a panacea but rather a natural process alternative to such methods as incineration, catalytic destruction, the use of absorbents, and physical removal and subsequent destruction of pollutants. The cost of moving and incinerating pollutants is at least ten times that of In situ biological treatment.

\subsection{Principle of Bioremediation}

There are three essential components needed for bioremediation. These three components are microorganisms, food, and nutrients. These three main components are known as the bioremediation triangle. Microorganisms are found almost everywhere on earth with the exception of active volcanoes. So a lack of food 
and nutrients are usually the missing ingredients that prevent successful bioremediation. Microorganisms find the food they eat in the soil or water where they live. However, if a contaminant is present it can become an additional food source for the microorganisms. The contaminant serves two useful purposes for the microbes. First, the contaminant provides a source of carbon needed for growth. Second, the microbes obtain energy by breaking chemical bonds and transferring electrons away from the contaminant. This is known as an oxidationreduction reaction. The contaminant that loses electrons is oxidized and the chemical that gains the electrons (electron acceptor) is reduced. The energy gained from the electron transfer is used along with the carbon and some electrons to produce more cells. Microbes generally use oxygen as an electron acceptor but nitrate, sulfate, iron, and $\mathrm{CO} 2$ are also commonly used. Most bioremediation systems are run under aerobic conditions, but running a system under anaerobic conditions ${ }^{9}$ may permit microbial organisms to degrade otherwise recalcitrant molecules.

\subsection{Role of biotechnology in bioremediation}

Biotechnology utilizes the application of genetic engineering to improve the efficiency and cost, which are key factors in the future widespread exploitation of microorganisms to reduce the environmental burden of toxic substances. The need of the most efficient environmental biotechnological process, researchers has devised a technique called bioremediation, in which is an emerging approach to rehabilitating areas contaminated by pollutants. Biological agents have proved their capacity for remediation, however, their long term and large scale use needs the application of genetic tools. Genetically modified microorganisms have shown the potential for bioremediation applications in groundwater, soil and activated sludge environments, exhibiting enhanced degradative capabilities encompassing a wide range of chemical contaminants ${ }^{\mathbf{1 0}}$. There are several examples where the use of biotechnology has increased the natural capacity of biological forms. Bacillus thuringensis has been used for the removal of oil spills. Deinococcus radiodurans (radioactive resistant bacteria) has been modified to consume and digest toluene and ionic mercury from highly radioactive waste. There is an example where bacterial cell wall is equipped with metal ion-binding polypeptides by the fusion of protein IgA protease of Neisseria gonorrhoeae, metallothionein (MT) from the rats and lpp-ompA to act as anchor ${ }^{11,12}$.

\subsection{Heavy metal pollution}

Heavy metal is a general collective term, which applies to the groups of metals and metalloids with atomic density greater than $4000 \mathrm{~kg} \mathrm{~m}^{-3}$, or 5 times more than water ${ }^{13}$ and they are natural components of the earth's crust. The most toxic forms of these metals in their ionic species are the most stable oxidation states e.g., $\mathrm{Cd}^{+2}, \mathrm{~Pb}^{+2}, \mathrm{Hg}^{+2}, \mathrm{As}^{+3}$ in which, they react with the bodies bio-molecules to form extremely stable bio-toxic compounds which are difficult to dissociate ${ }^{14}$. Heavy metal poisoning can result from drinking water contamination (e.g., lead pipes, industrial and consumer wastes), intake via the food chain or high ambient air concentrations near emission sources ${ }^{15}$. The diffusion phenomenon of contaminants through soil layers and the change in mobility of heavy metals in aquifer with intrusion of organic pollutants are being studied in more details in recent years ${ }^{16}$. With rapid industrialization pollution is in rapid increase. Pollution of soils with heavy metals is becoming one of the most severe environmental and human health hazards. Elevated levels of heavy metals not only decrease soil microbial activity and crop production, but also threaten human health through the food chain. Excessive levels of heavy metals can be damaging to the organism. Some of them are dangerous to health or environment (e.g., mercury, cadmium, lead, chromium) ${ }^{17}$, some may cause corrosion like zinc and some are harmful in other ways like arsenic may pollute catalysts.

\subsection{Heavy metals in ground water: sources, chemical property and speciation:}

Heavy metals occur in the earth's crust and may get solubilized in ground water through natural processes or by change in soil $\mathrm{pH}$. Moreover, groundwater can get contaminated with heavy metals from landfill leachate, sewage, leachate from mine tailings, deep well disposal of liquid wastes, seepage from industrial wastes lagoons or from industrial spills and leaks ${ }^{18}$. A variety of reactions in soil environment e.g. acid/base, oxidation/reduction, precipitation/dissolution, sorption or ion exchange processes can influence the speciation and mobility of metal contaminants. The rate and extent of these reactions will depend on factors such as $\mathrm{pH}$, Eh, complexation with other dissolved constituents, sorption and ion exchange capacity of the geological materials and organic matter content. The toxicity, mobility, and reactivity of heavy metals depend on its speciation, which again depends upon some conditions e.g. $\mathrm{pH}$, Eh, temperature, moisture, etc. In order to determine the speciation of metals in soils, specific extractants are used to solubilize different phases of metals $^{19,20}$.

\section{Microorganisms Used In Bioremediation:}

Microorganisms play an important role on nutritional chains that are an important part of the biological balance in the life in our planet. They are essential for the closing of nutrient and geochemical cycles such as 
carbon, nitrogen, sulfur, and phosphorous cycle ${ }^{21-24}$. Bioremediation involves the removal of the contaminated material to be treated elsewhere. Some examples of bioremediation technologies are phytoremediation, bioventing, bioleaching, landfarming, bioreactor, composting and biostimulation ${ }^{25-30}$.

Microorganisms that carry out biodegradation in many different environments are identified as active members of microbial consortiums. These microorganisms include: Xanthofacter, Penicillium, Bacillus, Pseudomonas, Flavobacterium, Mycrobacterium, Nitrosomonas etc ${ }^{7}$. There are some groups of microbes which are being used in bioremediation such as;

2.1 Aerobic: Aerobic bacteria recognized for their degradative abilities are Pseudomonas, Sphingomonas, Rhodococcus and Mycobacterium. These microbes have often been reported to degrade pesticides and hydrocarbons, both alkanes and polyaromatic compounds. Many of these bacteria use the contaminant as the sole source of carbon and energy.

2.2 Anaerobic: Anaerobic bacteria are not as frequently used as aerobic bacteria. There is an increasing interest in aerobic bacteria used for bioremediation of polychlorinated biphenyls in river sediments, dechlorination of the solvent trichloroethylene and chloroform.

The goal in bioremediation is to stimulate microorganisms with nutrients and the other chemicals that will enable them to destroy the contamination. Microbes could be isolated from almost all types of environmental conditions and also had a wide range of adaptability. It can survive from zero to extremely high and desert conditions. In water, it can survive in presence and absence of oxygen and also in presence of hazardous compounds or waste stream. Bacteria, fungi, yeast and algae can remove heavy metals and radionuclide from aqueous solution in substantial quantities. To survive under metal stressed condition, bacteria have evolved several types of mechanisms. These mechanisms of removal of heavy metals include the efflux of metal ions outside the cell, accumulation and forms complex of the metal ions inside the cell and later reduce the toxic metal ions to a non-toxic state. The microorganisms involved in this process may belong to bacteria, fungi, yeast and algae. Potent metal biosorbents under the class of bacteria include the genera of Bacillus, Pseudomonas, Streptomyces and P. aeruginosa $\mathbf{3}^{31,32,33}$. Amongst the various microorganisms, fungal biomasses were very effective due to presence of high percentage of cell wall material, which may have the excellent metal binding capacity. Many fungi and yeast have excellent biosorption potential includes the genera of Rhizopus, Aspergillus, Streptoverticullum and Sacchromyces ${ }^{34}$.

High levels of heavy metals are harmful to biota in environment including microorganisms. For endurance under metal-stressed environment, plant growth promoting Rhizobacteria have evolved several mechanisms by which they can immobilize, mobilize or transform metals rendering them inactive to tolerate the uptake of heavy metal ions. These mechanisms include:- (1) Exclusion-the metal ions are kept away from the target sites; (2) Extrusion-the metals are pushed out of the cell through chromosomal/plasmid mediated events; (3) Accommodation- metals form complex with the metal binding proteins or other cell components; (4) Biotransformation- toxic metal is reduced to less toxic forms; and (5) Methylation and Demethylation. Thus, in general the immobilization and mobilization are the two main techniques used for the bioremediation of metals by microbes.

\section{Types Of Bioremediation:}

On the basis of removal of wastes for treatment there are basically two methods:-

1. In situ bioremediation

2. Ex situ bioremediation

\subsection{In situ bioremediation}

In situ bioremediation is the application of bioremediation in the subsurface as compared to ex situ bioremediation, which applies to media readily accessible aboveground (e.g., in treatment cells/soil piles or bioreactors). In situ bioremediation may be applied in the unsaturated zone (e.g., bioventing) or in saturated soils and groundwater. In situ bioremediation technology was originally developed as a less costly, more effective alternative to the standard pump-and-treat methods used to clean up aquifers and soils contaminated with organic chemicals(e.g., fuel hydrocarbons, chlorinated solvents), but has since expanded in breadth to address explosives, inorganics (e.g., nitrates), and toxic metals (e.g., chromium). It is a superior method to cleaning contaminated environments since it is cheaper and uses harmless microbial organisms to degrade the chemicals. Chemotaxis is important to the study of in situ bioremediation because microbial organisms with chemotactic abilities can moves into an area containing contaminants. So by enhancing the cells chemotactic abilities, in-situ bioremediation will become a safer method in degrading harmful compounds. 


\subsubsection{Types of In situ Bioremediation}

\subsubsection{Intrinsic bioremediation:}

Intrinsic bioremediation manages the innate capabilities of naturally occurring microbial communities to degrade environmental pollutants without taking any engineering steps to enhance the process. This approach deals with stimulation of indigenous or naturally occurring microbial population by feeding them nutrients and oxygen to increase their metabolic activity.

\subsubsection{Engineered In situ bioremediation:}

The second approach involves the introduction of certain microorganism to the site of contamination. Engineered in situ bioremediation accelerates the degradation process by enhancing the physicochemical conditions to encourage the growth of microorganism.

\subsubsection{Advantages of In situ Bioremediation}

- It may be possible to completely transform organic contaminants to innocuous substances (e.g., carbon dioxide, water, ethane).

- Accelerated In situ bioremediation can provide volumetric treatment, treating both dissolved and sorbed contaminant.

- The time required to treat subsurface pollution using accelerated In situ bioremediation can often be faster than pump-and-treat processes.

- In situ bioremediation often costs less than other remedial options.

- The areal zone of treatment using bioremediation can be larger than with other remedial technologies because the treatment moves with the plume and can reach areas that would otherwise be inaccessible.

\subsubsection{Limitations of In situ Bioremediation}

- Depending on the particular site, some contaminants may not be completely transformed to innocuous products.

- If biotransformation halts at an intermediate compound, the intermediate may be more toxic and/or mobile than the parent compound.

- Some contaminants cannot be biodegraded (i.e., they are recalcitrant).

- When inappropriately applied, injection wells may become clogged from profuse microbial growth resulting from the addition of nutrients, electron donor, and/or electron acceptor.

- Heavy metals and toxic concentrations of organic compounds may inhibit activity of indigenous microorganisms.

- In situ bioremediation usually requires an acclimatized population of microorganisms, which may not develop for recent spills or for recalcitrant compounds.

\subsection{Ex situ bioremediation}

Ex situ bioremediation is a biological process in which excavated soil is placed in a lined above ground treatment area and aerated following processing to enhance the degradation of organic contaminants by the indigenous microbial population. This process requires excavation of contaminated soil or pumping of groundwater to facilitate microbial degradation.

\subsubsection{Types of Ex situ bioremediation}

Ex-situ bioremediation is further divided into slurry-phase bioremediation and solid-phase bioremediation.

\subsubsection{Slurry-phase:}

Slurry-Phase bioremediation, also known as bioreactors, is a controlled treatment that involves the excavation of the contaminated soil, mixing it with water and placing it in a bioreactor. This processing involves the separation of stones and rubbles from the contaminated soil. Next, the soil is mixed with a predetermined water amount to form the slurry. The concentration of water added depends on the concentration of pollutants, the rate of biodegradation, and the physical nature of the soi ${ }^{35}$. When this process is done the soil is removed and dried up using pressure filters, vacuum filters or centrifuges. The next procedure is the disposition of the soil and further treatment of the resulting fluids.

\subsubsection{Solid-phase:}

Solid-Phase bioremediation is an ex-situ technology in which the contaminated soil is excavated and placed into piles. It is also includes organic wastes like leaves, animal manures and agricultural wastes, problematic waste e.g. domestic and industrial waste and municipal solid wastes. Bacterial growth is stimulated through a network off pipes that are distributed throughout the piles ${ }^{36}$. By pulling air through the pipes the 
necessary ventilation is provided for microbial respiration. Solid-phase systems require a large amount of space, and cleanups require more time to complete than with slurry-phase processes. Some solid-phase treatment processes include land farming, soil biopiles, and composting.

\subsection{Landfarming}

The goal of this technique is to stimulate indigenous biodegradative microorganisms and facilitate their aerobic degradation of contaminats. It is a simple technique in which contaminated soil is excavated and spread over a prepared bed and periodically tilled until pollutants are degraded. Nutrients and minerals are also added to promote the growth of the indigenous species.

\subsection{Soil biopiles}

Soil biopiles, also known as biocells, is a biodegradation technique used for the remediation of excavated soil contaminated with petroleum contents. This technology involves the accumulation of contaminated soil into piles and the stimulation of microbial activity either aerobically or by the addition of nutrients, minerals or moisture. A typical height of biopiles is between three and ten feet. Biopiles are in a way similar to landfarms due to the fact that this technology also uses oxygen as a way to stimulate bacterial growth. However, while tilling or plowing aerates land farms, biopiles are aerated by forcing air to move by injection through perforated piping placed throughout the pile ${ }^{35,36}$.

\subsection{Composting}

Composting involves mixing the contaminated soil with a bulking agent such as straw, hay, or corncobs to make it easier to deliver the optimum levels of air and water to the microorganisms. Mechanically agitated composting involves the placement of the contaminated soil in treatment vessels where it is mixed to achieve aeration. In window composting, the soil is placed in long piles knows as windows and periodically mixed by tractors ${ }^{37}$. A typical ratio of soil to compost is $75 \%$ contaminated soil to $25 \%$ compost. This ratio is changeable depending on the soil type, contaminants level and characteristics. Compost remediation is known to have faster cleanup results since cleanup can be estimated in terms of weeks instead of months.

\subsubsection{Advantages:}

- Suitable for a wide range of contaminants.

- Suitability relatively simple to assess from site investigation data.

\subsubsection{Limitations:}

- Not applicable to heavy metal contamination or chlorinated hydrocarbons such as trichloroethylene.

- Non-permeable soil requires additional processing (clays and silts

\section{Advantages Of Bioremediation:}

- Bioremediation is a natural process and is therefore perceived by the public as an acceptable waste treatment process for contaminated material such as soil. Microbes able to degrade the contamination increase in number when contaminant is present; when the contaminant degraded, the biodegradative population declines.

- Less energy is required as compared to other technologies.

- Bioremediation can prove less expensive than other technologies that are used for clean-up of hazardous waste.

- Bioremediation is useful for the complete destruction of a wide variety of contaminants. Many compounds that are legally considered to be hazardous can be transformed to harmless products.

- Instead of transferring contaminants from one environment medium to another, for e.g. from land to water or air, the complete destruction of target pollutants is possible.

\section{Disadvantages Of Bioremediation:}

- Biological processes are often highly specific. Important site factors required for success include the presence of metabolically capable microbial populations, suitable environmental growth conditions, and appropriate levels of nutrients and contaminants.

- Bioremediation often takes longer than other treatment options, such as excavation and removal of soil or incineration.

- Contaminants may be present as solids, liquids and gases.

- Dynamic process, difficult to predict future effectiveness. 
- Bioremediation is limited to those compounds that are biodegradable. Not all compounds are susceptible to rapid and complete degradation.

Regulatory uncertainty remains regarding acceptable performance criteria for bioremediation. There is no accepted definition of bioremediation and there are no acceptable endpoints of bioremediation treatment. To evaluate performance of bioremediation is difficult. Bioremediation is not only an effective degradation of pollutants but it can also be used to clean unwanted substances from air, soil, water and raw materials from industrial waste ${ }^{38}$.

\section{Conclusion}

Bioremediation is a powerful tool available to clean up contaminated sites. The idea of bioremediation has a long history. However, other applications are relatively new and many other applications are emerging or being developed. Bioremediation occurs when the microorganisms can biodegrade the given contaminant and the necessary nutrients such as nitrogen, phosphorus, electron acceptors, and trace elements. This process can be aerobic or anaerobic depending on the microorganisms and the electron acceptors available. This process may be natural (intrinsic bioremediation) or it may be enhanced by man (engineered bioremediation). Regardless of which aspect of bioremediation that is used; this technology offers an efficient and cost effective way to treat contaminated ground water and soil.

\section{References}

[1]. S.P.B.K. Kamaludeen, K.R. Arunkumar, S. Avudainayagam, K. Ramasamy, Bioremediation of chromium contaminated environments, Ind. J. Exp Bio. 41, 2003, 927-985.

[2]. P.J. Strong, J.E. Burgess, Treatment methods of wine-related and distillery wastewater: a review, Biorem. Jo. 12, 2008, 70-87.

[3]. A. Hess, B. Zarda, D. Hahn, A. Hanner, D. Stax, In situ analysis of denitrifying toluene amd m-xylene degrading bacteria in a diesel fuel contaminated laboratory aquifer colum, J. App. Enviro. Micro., 63, 1997, 2136-2141.

[4]. C.Y. Tang, Q.S. Criddle, C.S. Fu, J.O. Leckie, Effect of flux (transmembrane pressure) and membranes properties on fouling and rejection of reverse osmosis and nanofiltration membranes treating perfluorooctane sulfonate containing waste water, Jou. Enviro. Sci. Tech. 41, 2007, 2008-2014.

[5]. A. Kumar, D. Chandel, I. Bala, A. Muwalia, L. Mankotiya, The IUP Journal of Biotechnology, 4 (2), $2010,45-56$.

[6]. M.H. Fulekar, Bioremediation of fenvalerate by Pseudomonas aeruginosa in a scale up bioreactor, Romanian Biotechnological Letters, 14(6), 2009, 4900-4905.

[7]. R. Singh, P. Singh, R. Sharma, Microorganism as a tool of bioremediation technology for cleaning environment: A review, Intrnational Academy of Ecology and Environmental Science, 4 (1), 2014, 1-6.

[8]. M. Vidali, Bioremediation An Overview, Pure Appl. Chem, 73(7), 2001, 1163-1172.

[9]. P. J. S. Colberg, L. Y. Young, Anaerobic Degradation of No halogenated Homocyclic Aromatic Compounds Coupled with Nitrate, Iron, or Sulfate Reduction. In Microbial Transformation and Degradation of Toxic Organic Chemicals, WileyLiss, New York, 1995, $307-330$.

[10]. S. Bhatnagar, R. Kumari, Bioremediation: A Sustainable Tool for Environmental Management- A review, Annual Review and Research in Biology, 3 (4), 2013, 974-993.

[11]. W. Bae, W. Chen, A. Mulchandani, R. K. Mehra, Enhanced bioaccumulation of heavy metals by bacterial cells by displaying synthetic phytochelatins, Biotechnol Biogen, 70, 2000, 518-524.

[12]. M. Valls, S. Atrian, V. Lorenzo, L. A. Fernadez, Engineering a mouse metallothionein on the surface of Ralstonia eutropha CH34 for immobilizationof heavy metals in soil, Nat Biotechnol, 18, 2000, 661-665.

[13]. J. R. Garbarino, H. Hayes, D. Roth, R. Antweider, T. I. Brinton, H. Taylor, Contaminants in the Mississippi river, U. S. geological survey circular, 1133, Virginia U.S.A. (www.pubs.usgs.gov/circ/circ1133/).

[14]. J. O. Duruibe, M. O. C. Ogwuegbu, J. N. Egwurugwu, Heavy metal pollution and the human biotoxic effects, International Journal of Physical Sciences, 2, 2007, 112-118.

[15]. Lenntech. Water treatment. Lenntech, Rotterdamseweg, Netherlands (Lenntech water treatment and Air purification). 2004

[16]. J. Cuevas, A.I. Ruiz, I.S. de. Soto, T. Sevilla, J.R. Procopio, P. Da. Silva, M.J. Gismera, M. Regadio, N. J. S. Rodriguez, M. Rastrero, S. Leguey, "The performance of natural clay as a barrier to the diffusion of municipal solid waste landfill leachates", Journal of Environmental Management. Doi: 10.1016/j.jenvman.2011.02.014,2011.

[17]. C. M. Hogan, Heavy metal. Encyclopedia of Earth, National Council for Science and the Environment. Eds. E. Monosson \& C. Cleveland. Washington, D. C.2010

[18]. C. R. Evanko, D. A. Dzombak, Remediation of Metals-contaminated Soils and Groundwater, Technology Evaluation Report, TE97-01. Groundwater Remediation Technologies Analysis center, Pittsburg, PA, 1997.

[19]. A. Tessier, P. G. C. Campbell, M. Bisson, Sequential extraction procedure for the speciation of particulate trace metals, Analytical Chemistry, 51, 1979,844-851.

[20]. M. A. Hashim, S. Mukhopadhyay, J. A. Sahu, B. Sengupta, Remediation technologies for heavy metal contaminated ground water, Journal of Enironmental Management, 92, 2011, 2355-2388.

[21]. B. C. Christner, C. E. Morris, C. M. Foreman, R. Cai, D. C. Sands, Ubiquity of biological ice nucleators in snowfall. Science, 319 (5867), 2008, 1214-1214

[22]. U. Szewzyk, R. Szewzyk, T. Stenstrom, Thermophillic Anaerobic bacteria isolated from a deep borehole in granite in Sweden. Proc Natl Acad Sci USA, 91(5), 1994, 1810-1813.

[23]. G. Horneck, Survival of microorganisms in space: a review, Adv Space Res, 1 (14),1981, 39-48.

[24]. R. Cavicchioli, Extremophiles and the search for extraterrestrial life. Astrobiology, 2(3), 2002, 281-92.

[25]. J. Barea, M. Pozo, R. Azcon, C. Azcon-Aguilar, Microbial co-operation in the rhizosphere. J Exp Bot, 56 (417), 2005, $1761-78$.

[26]. Gillen, L. Alan, The Genesis of Germs: The Origin of Diseases and the Coming Plagues (New Leaf Publishing Group, 2007, 10).

[27]. N. F. Gray, Biology of wastewater treatment, Imperial College Press, 2004, 1164.

[28]. Kitani, Osamu, Carl W. Hall (1989). Biomass Handbook. Taylor \& Francis US, 256. 
[29]. Tickell, Joshua et al, From the Fryer to the Fuel Tank: The Complete Guide to Using Vegetable Oil as an Alternative Fuel. Biodiesel America, 2000, 53.

[30]. Inslee, Jay et al. (2008). Apollo's Fire: Igniting America’s Clean Energy Economy. Island Press.p. 157.

[31]. S. Tunali, A. Cabuk, T. Akar, Removal of lead and copper ions from aqueous solutions by bacterial strain isolated from soil, Chemical Engineering Journal, 115, 2006, 203-211

[32]. G. Uslu, M. Tanyol, Equilibrium and thermodynamic parameters of Single and_binary mixture biosorption of lead and copper ions onto Pseudomonas putida: effect of temperature, Journal of Hazardous Materials, 135, 2006, 87-93.

[33]. E. M. Soltan, Isolation and characterization of antibiotic and heavy metal resistant Pseudomonas aeroginosa from different polluted waters in Sohag District, Egypt, Microbial Biotechnology, 11, 2001, 50-55.

[34]. P. R. Puranik, K. M. Paknikar, Biosorption of lead and zinc from solutions using Streptoverticillium cinnamoneum waste biomass, Journal of Biotechnology, 55, 1997,113-124.

[35]. EPA, (2003), Underground Storage Tanks. www.epa.gov/swerust1/ustsystm/erpdoc.pdf.

[36]. M. Hyman, R. R. Dupont, Groundwater and Soil Remediation. Process Design and Cost Estimating of Proven Technologies, ASCE Press, 2001.

[37]. C. J. Cunningham, J. C. Philip, Comparison of Bioaugmentation and Biostimulation in ex situ Treatment of Diesel Contaminated Soil, Land Contamination and Reclamation, University of Edinburgh, Scotland. 2000.

[38]. Md. Zeyaullah, Md. Atif, Islam Badrul, S. Azza, I. Abdelkafe, P. Sultan, Md. A. ElSaady, A. Arif); Bioremediation: A tool for environmental cleaning, African Journal of Microbiology Research, 3(6), 2009, 310-314. 